\title{
Zinc oxide nanoparticles at environmentally relevant concentrations cause cytotoxic and chromosomal damage to Allium cepa root cells
}

\author{
L.L.G. Sampaio ${ }^{1}$, É.P.C. Bogea ${ }^{1}$, E.L. Neves ${ }^{1}$, L. de M.O. Mendes ${ }^{2}$, \\ É.F.L. Araújo ${ }^{1}$, M.O. Baia ${ }^{1}$, J.O. da Silva ${ }^{3}$, G. Malafaia ${ }^{1}$ and \\ I.P.P. de Menezes ${ }^{1}$ \\ ${ }^{1}$ Programa de Pós-Graduação em Conservação de Recursos Naturais do \\ Cerrado e Laboratório de Genética Molecular, Instituto Federal Goiano, \\ Campus Urutaí, GO, Brasil \\ ${ }^{2}$ Programa de Pós-Graduação em Proteção de Plantas e Laboratório de \\ Genética Molecular, Instituto Federal Goiano, Campus Urutaí, GO, Brasil \\ ${ }^{3}$ Programa de Pós-Graduação em Proteção de Plantas e Laboratório de \\ Genética Molecular, Universidade Estadual de Goiás, Campus Ipameri, GO, \\ Brasil
}

Corresponding author: I.P.P. de Menezes E-mail: ivandilson.menezes@ifce.edu.br

Genet. Mol. Res. 20 (1): gmr18690

Received December 02, 2020

Accepted January 21, 2020

Published February 28, 2021

DOI http://dx.doi.org/10.4238/gmr18690

ABSTRACT. Although environmental toxicity of high concentrations of nanoparticles (NP) is well reported in the literature, information about their effects on biological systems at environmentally relevant concentrations remains scarce. We investigated whether low $\mathrm{ZnO}-\mathrm{NP}$ concentrations influence the dynamics of cell division processes, cause nuclear abnormalities and induce changes in the genomic DNA using Allium cepa root cells. Healthy A. cepa bulbs were exposed to environmentally relevant concentrations of $\mathrm{ZnO}-\mathrm{NP}$ for 48 hours under four different environmental conditions, namely: optimistic, median, pessimistic and known toxic. Mitotic index (MI), chromosomal abnormalities (CAs) and genomic stability based on DNA markers were estimated. ZnO-NPs induced significant changes in MI and CAs, with clear dose-response effects, even at very low concentrations and short exposure times. This outcome is clear evidence of negative effects. In addition, we evidenced instability in the repair mechanism of DNA mutated due to low concentrations of $\mathrm{ZnO}$ NPs based on RAPD-PCR 
results. Therefore, even short-term exposure of eukaryotic cells to low concentrations of $\mathrm{ZnO}-\mathrm{NP}$ can damage cells and, consequently, negatively affect their biological functioning.

Key words: Phytotoxicity; Nanotoxicity; Nanomaterials; DNA integrity

\section{INTRODUCTION}

The commercial application of nanoparticles (NPs) is a technological innovation that has offered countless opportunities to services and products worldwide, as well as that has favored several industrial sectors, such as the biotechnological, agricultural, food, cosmetic and health ones (Stroher et al., 2010; Rai et al., 2012; Singh et al., 2018). The increase by approximately $3,000 \%$ in the number of products inventoried between 2005 and 2014 in 622 companies distributed among 32 countries, showed indisputable commercial and economic gain (Vance et al., 2015). The great potential to create new products with nanoscale substances is the reason behind this success, since it has assigned new properties to such products, as well as improved their quality and efficiency (Wang, 2020). Although this sharp increase has indicated the growing popularity of products using nanotechnology, their potential effect on the environment and on human health remains uncertain.

The continuous growth in the demand for NP production and application at commercial scale accounts for assuming inevitable direct and indirect disposal of these substances into the environment (Gottschalk et al., 2011). It is consensus that environmental pollution is a serious and growing issue worldwide, but it has worsened in recent years due to pollutants' nano-size. The permanent exposure of living organisms to NPs and, consequently, to their intrinsic properties - such as wide nano-gamma variation (at the order of 1-100 nm) -, varied chemical composition, agglomeration capacity, high persistence, wide distribution and biocompatibility, can make NP translocation to organic systems easier and lead to different toxic effects (Ma et al., 2010).

Zinc is the fourth most used metal (after iron, copper and aluminum); its market currently stands at 11.6 million tons a year (https://www.zinc.org). ZnO NPs are among the most used nanoparticles to produce nanotechnology-based goods, such as sunblock, cosmetics, paint, as well as to process rubber, to dye fabric and to treat wastewater (Vance et al., 2015), consequently, it is inevitable to have a substantial amount of nanoparticles flowing into the environment. Recent scientific publications have warned about the potential risks associated with ZnO NPs. Lin and Xing (2008) reported deformities in rye roots caused by the high number of cells that collapse due to the exposure to high concentrations of $\mathrm{ZnO}$ NPs. Based on Kumari et al. (2011), ZnO NPs emerged as clastogenic and cytotoxic agent in cytogenetic tests applied to Allium cepa. Ghodake et al. (2011) found that ZnO NPs blocked the growth stages of $A$. cepa roots due to their accumulation in the root system, as well as caused severe damages at cell and chromosomal level. Sun et al. (2019) demonstrated the adverse effects of toxicity in A. cepa, among them one finds root-development inhibition, membrane-integrity loss, decreased metabolic activity, DNA damage and cell death. These effects were caused not only by $\mathrm{Zn}^{2+}$ released by ZnO NPs, but by the NPs themselves. Although the aforementioned studies are relevant for environmental monitoring, they report the toxic effects of ZnO NPs at concentrations far from those found in the field; therefore, these concentrations are much higher than the ones 
found in the environment (Boxall et al., 2007; Gottschalk et al., 2013; Dumont et al., 2015). The literature still lacks studies focused on evaluating the cytotoxic and genotoxic effects of the exposure to environmentally relevant concentrations of NPs, except for Souza et al., (2018) and Mesak et al., (2018), who showed behavioral changes in mammals and birds due to the exposure to such concentration rates.

It is essential to assess the phytotoxic effects of NPs on environmental conditions that simulate the field conditions of different parameters and biological systems in order to produce to understand their environmental impact. Plant systems have a wide variety of well-defined genetic parameters, including polyploid changes, nuclear fragmentation and mitotic abnormality (Kumari et al., 2011; Fatma et al., 2017). A. cepa is a standard and robust plant system model used in cytotoxic, genotoxic and mutagenic assays aimed at monitoring the environmental impacts of chemical substances all over the world. This plant species was validated by the International Program on Chemical Safety (IPCS, WHO) and by the United Nations Environmental Program (UNEP).

Our study was based on the hypothesis that predicted environmental concentrations of $\mathrm{ZnO}$ NPs can cause nuclear fragmentation and increase mitotic anomalies in the meristematic cells of $A$. cepa roots. Therefore, the aim of our research was to evaluate the cytotoxic and genotoxic effects of environmentally relevant concentrations of $\mathrm{ZnO}$ NPs on A. cepa. We quantified the $\mathrm{Zn}$ concentration in the roots of $A$. cepa exposed to environmentally relevant concentrations of $\mathrm{ZnO}$ nanoparticles to determine whether environmentally relevant concentrations of $\mathrm{ZnO} \mathrm{NPs}$, would be capable of causing cell division anomalies and affect DNA stability.

\section{MATERIALS AND METHODS}

\section{Chemical characterization of ZnO NPs}

The herein used ZnO NPs (purity $>99.99 \%$ ) were purchased at Sigma Aldrich (Saint Louis, MO, USA; CAS number 1314-13-2). The chemical characterization, the distribution of the individual diameter of each $\mathrm{ZnO} \mathrm{NP}, \mathrm{X}$-ray diffraction patterns of the crystal quality of $\mathrm{ZnO}$ nanoparticles and fourier transform-infrared transmission spectra were previously calculated by the research group (Souza et al., 2018). ZnO NPs showed no trace of impurity, but they presented crystalline morphology and polygonal particles, as well as diameter consistent with the manufacturer's recommendations: $68.96 \pm 33.71 \mathrm{~nm}$.

\section{Preparation of NPs}

Initially, $\mathrm{ZnO} \mathrm{NP}(500 \mu \mathrm{g} / \mathrm{L})$ stock solution was prepared in purified water (via reverse osmosis) and dispersed through ultrasonic vibration (Eco - Sonics, Ultronique) for $30 \mathrm{~min}$ to avoid aggregation. Next, four test concentrations were prepared and immediately used in the experiment. Three (3) of these concentrations were environmentally relevant: $1.5 \mathrm{ng} / \mathrm{L}, 360 \mathrm{ng} / \mathrm{L}$ and 7.6x10 $0^{5} \mathrm{ng} / \mathrm{L}$ (Boxal et al., 2007; Dumont et al., 2015); one of them was known to be toxic $\left(1 \times 10^{8} \mathrm{ng} / \mathrm{L}\right)$ (Kumari et al., 2011). These treatments were defined as the tested environmental conditions.

The environmentally relevant concentration of $\mathrm{ZnO}$ NPs was defined based on Dumont et al., (2015) and Boxal et al., (2007), who used the global water availability 
assessment model (GWAVA) to simulate exposure processes based on the current production level of $\mathrm{ZnO}$ NPs in surface water. This model also takes into consideration the fraction of these NPs found in cosmetic and personal hygiene products, paint and, mainly, in sunblock. Their simulation was based on the representative period of 31 years of monthly collected meteorological data. According to these authors' predictions, concentration of $7.6 \times 10^{5} \mathrm{ng} / \mathrm{L}$ depicted a pessimistic scenario, since it evidenced negligence in removing these nanomaterials from polluted rivers and in domestic or industrial waste treatment before its disposal into waterbodies. Their predictions also showed two other likely scenarios based on efficient domestic or industrial sewage treatments prior to waste disposal into waterbodies: $i$ ) Median scenario: mean concentration of $360 \mathrm{ng} / \mathrm{L}$ in $10 \%$ river body; and $i$ ) Optimistic scenario: based on mean concentration of $1.5 \mathrm{ng} / \mathrm{L}$ in half river body. The toxic concentration $\left(1 \times 10^{8} \mathrm{ng} / \mathrm{L}\right)$ was selected based on the study by Kumari et al. (2011), who observed that $\mathrm{ZnO}$ NPs can be cytotoxic, clastogenic and genotoxic for A. cepa.

\section{Experimental design}

Eighteen (18) healthy onion bulbs (mean weight 20-30 g), belonging to variety aquarius, were carefully selected in the local market. All selected onion bulbs were washed in running water; dried outer scales were removed before the onions were used in the experiment. They were distributed into six experimental groups of $n=3$ bulbs and exposed to different aqueous $\mathrm{ZnO}$ concentrations for $48 \mathrm{~h}$, namely: i) negative control (NC) - bulb root area (root base) immersed to pure water (reverse osmosis); ii) positive control (PC) bulb root area immersed to $50 \mathrm{mg} / \mathrm{L}$ of cyclophosphamide (which is a drug known for its mutagenicity); iii) the Optimistic group - bulb root area immersed to low concentration of $\mathrm{ZnO}$ NPs (1.5 ng/L); iv); Median group - bulb root area immersed to solution with $360 \mathrm{ng} / \mathrm{L}$ of $\mathrm{ZnO}$; v); Pessimistic group - bulbs immersed to $7.6 \times 10^{5} \mathrm{ng} / \mathrm{L} \mathrm{ZnO}$; and vi) Presumably Toxic group - bulbs immersed to solution with $1 \times 10^{8} \mathrm{ng} / \mathrm{L}$ of $\mathrm{ZnO}$.

Onion bulbs in each treatment were suspended in cylinder ( $5 \mathrm{~cm}$ in height) produced with 50-mm PVC (polyvinyl chloride) brown barrels. The container of each bulb was exposed to the treatment that was deposited in a black polyethylene carton $(32 \mathrm{~cm}$ in length $\mathrm{x} 12 \mathrm{~cm}$ in width $\mathrm{x} 11 \mathrm{~cm}$ in height) (Figure 1).

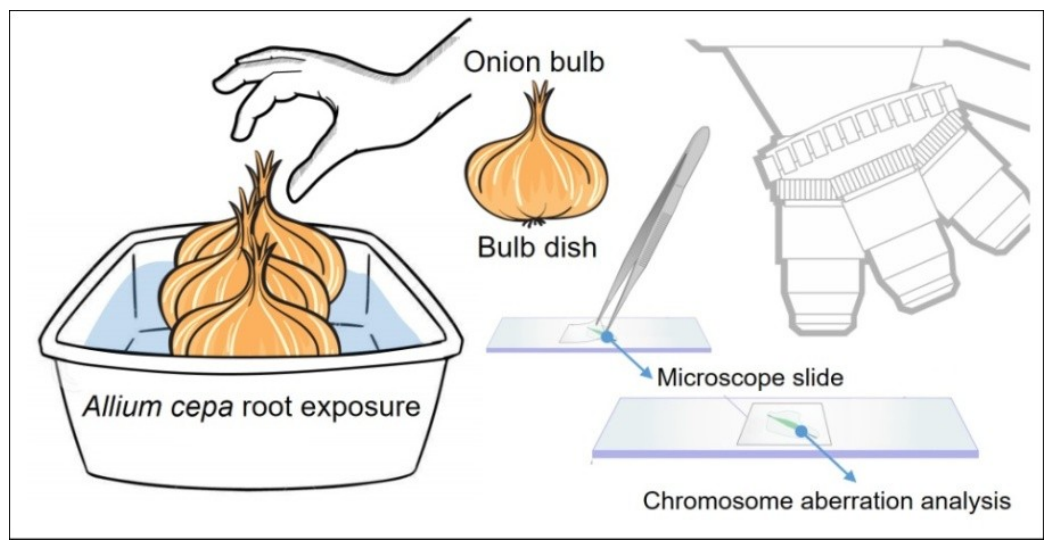

Figure 1. Schematic drawing of the experimental design. 
Onion bulbs were exposed to each treatment for $48 \mathrm{~h}$, the roots were cut with a scalpel and separated for further analysis. Four (4) roots (1 to $2 \mathrm{~cm}$ in length) - one from each bulb, in each treatment -, were used for DNA extraction, in separate. The remaining roots of each bulb, from each treatment, were distributed into two sampling groups and transferred to $2 \mathrm{~mL}$ polypropylene microtubes. One sample group was frozen at $-20^{\circ} \mathrm{C}$ for $\mathrm{Zn}$ concentration quantification and the other sample group was kept in Carnoy 3:1 fixation solution (ethanol:acetic acid, v/v) for $6 \mathrm{~h}$. Subsequently, the Carnoy fixation solution was renewed and stored at $4^{\circ} \mathrm{C}$ for further use.

\section{Quantification of Zn Bioaccumulation}

Six (6) subgroups of roots from three onions that were subjected to each tested concentration were used to determine $\mathrm{Zn}$ bioaccumulation. They were macerated and digested in screw cap sample beaker with $2 \mathrm{~mL}$ of digestion solution $(75 \%$ nitric acid $\left(\mathrm{HNO}_{3}\right): 70 \%$ perchloric acid $\left.\left(\mathrm{HClO}_{4}\right)=1: 1 \mathrm{v} / \mathrm{v}\right)$. The beaker was placed on heating plate at $100^{\circ} \mathrm{C}$ for $2 \mathrm{~h}$. After sample digestion was complete, the cap was removed and the heating process continued at $80^{\circ} \mathrm{C}$ until the drying process was complete. Next, sample digestion waste was kept at room temperature and re-suspended in $5 \mathrm{~mL}$ of $\mathrm{HNO}_{3}(5 \%)$. The solution was used to measure the total $\mathrm{Zn}$ content through inductively coupled plasma mass spectrometry (ICP-MS). Calibration standards of $0.1,1.0$ and $10 \mathrm{mg} / \mathrm{kg} \mathrm{Zn}$ were used to validate the method. All samples were analyzed in duplicate to ensure reproducibility. Finally, Zn concentration in the roots was expressed in $\mu \mathrm{g} / \mathrm{g}$ of dry weight tissue.

\section{Microscopic analysis}

Genotoxic and mutagenic potential evaluation was based on identifying and counting nuclear anomalies in meristematic cells of $A$. сеpa roots. Slides for optical microscopy observation were prepared based on the following procedures: roots were hydrolyzed in $\mathrm{HCl}(1 \mathrm{M})$ at $80^{\circ} \mathrm{C}$ for $10 \mathrm{~min}$ and stained with $45 \%$ Safranin for $20 \mathrm{~min}$. The meristematic region of the root (which is located $2-3 \mathrm{~mm}$ from the tip) was sectioned and taken to the lamina, which was macerated with a cover slip and examined under light microscopy at 1000x magnification.

In total, 15,000 cells were analyzed in each treatment, thus totaling fifteen slides (five for each onion) per treatment; 1000 cells were analyzed per slide. Cytotoxicity was quantified based on the mitotic index (MI), which was calculated based on the ratio between the number of cells under division and the total number of observed cells. Genotoxicity was assessed based on the chromosomal abnormality index (CAs), which was established by the ratio of cells presenting chromosomal anomalies and the total number of observed cells. Finally, the chromosomal anomaly index per mitotic division phase was used to estimate the percentage of cells presenting chromosomal anomalies per phase (prophase, metaphase, anaphase and telophase).

\section{DNA stability analysis}

DNA integrity and stability analysis was performed based on the electrophoresis profile by using seven RAPD primers; the analysis was performed in duplicate for control 
purposes. Changes in the loss or gain scores of product amplification were compared to those of the control group. The model adopted to estimate Genomic Stability (\%) was calculated through "EG = $100-(100 \mathrm{a} / \mathrm{n})$ "; wherein, "a" is the mean number of changes in DNA profiles and " $n$ " is the number of amplified bands in the control DNA profile, based on Ozakca and Silah (2013).

One root bulb was separated from each experimental group for genomic DNA extraction after the exposure to ZnO NPs for 48 hours, based on the 2\% CTAB method. Genomic DNA amplification through PCR followed the manufacturer's recommendations, with modification: final volume of $15 \mu \mathrm{L}$ in each PCR, $20 \mathrm{ng}$ DNA, $1 \mathrm{x}$ PCR buffer, $1.5 \mathrm{mM}$ $\mathrm{MgCl}_{2}, 0.2 \mathrm{mM}$ dNTPs, $0.2 \mu \mathrm{M}$ of each primer and $1 \mathrm{U}$ Taq DNA polimerase Platinum Invitrogen. Amplification was performed in thermocycler under conditions recommended by Ozakca and Silah (2013): initial denaturation at $94^{\circ} \mathrm{C}$ for $5 \mathrm{~min}$. This procedure was followed by 45 cycles, which comprised three phases: 1) denaturation at $94^{\circ} \mathrm{C}$ for $45 \mathrm{~s}, 2$ ) annealing at $39^{\circ} \mathrm{C}$ for $60 \mathrm{~s}$, and 3) extension at $72^{\circ} \mathrm{C}$ for $45 \mathrm{~s}$. Finally, one final extension was ran at $72^{\circ} \mathrm{C}$ for $15 \mathrm{~min}$. Amplified products were stored at $4^{\circ} \mathrm{C}$ for further analysis through electrophoresis. The aliquot of $9.0 \mu \mathrm{L}$ of each PCR product was subjected to agarose gel electrophoresis $(2 \%)$ at $50 \mathrm{~V}$ for $2 \mathrm{~h}$ and, subsequently, stained with ethidium bromide.

\section{Data analysis}

Data were subjected to Shapiro-Wilk normality test and to Levene homoscedasticity test, as well as to analysis of simple variance (ANOVA one-way) with Tukey test, at 5\% probability - when F was statistically significant. Data were subjected to Kruskal-Wallis test, followed by Dunn's test, at 5\% probability level, when there was no adherence to normal data distribution. Correlation analysis was performed through the Spearman method. All analyses and graphs were plotted in the GraphPad Prism software (version 6.0).

\section{RESULTS AND DISCUSSION}

Different environmentally relevant concentrations of $\mathrm{ZnO}$ nanoparticles (NPs) led to cell damages and to behavioral dysfunctions in the chromosomes of meristematic cells in the roots of $A$. cepa. The $A$. cepa model is simple and efficient to evaluate the toxic effects of several contaminants, such as high and low concentrations of NPs (Kumari et al., 2009; Modlitbová et al., 2018; Sun et al., 2019), in short-run exposure assays.

\section{Bioaccumulation analysis}

The bioaccumulation analysis applied to root tissues of $A$. cepa showed $\mathrm{Zn}$ concentration increase as the concentration of $\mathrm{ZnO}$ NPs also increased in the experimental groups. However, the comparison between the lower concentrations and the higher concentrations of ZnO NPs showed statistical differences. There was significant increase in the pessimistic and toxic concentrations when they were compared to the controls (Figure 2). Cytotoxic and genotoxic damages were observed in all concentrations, even when there was significant different increase in all peer-to-peer comparisons (see below). 


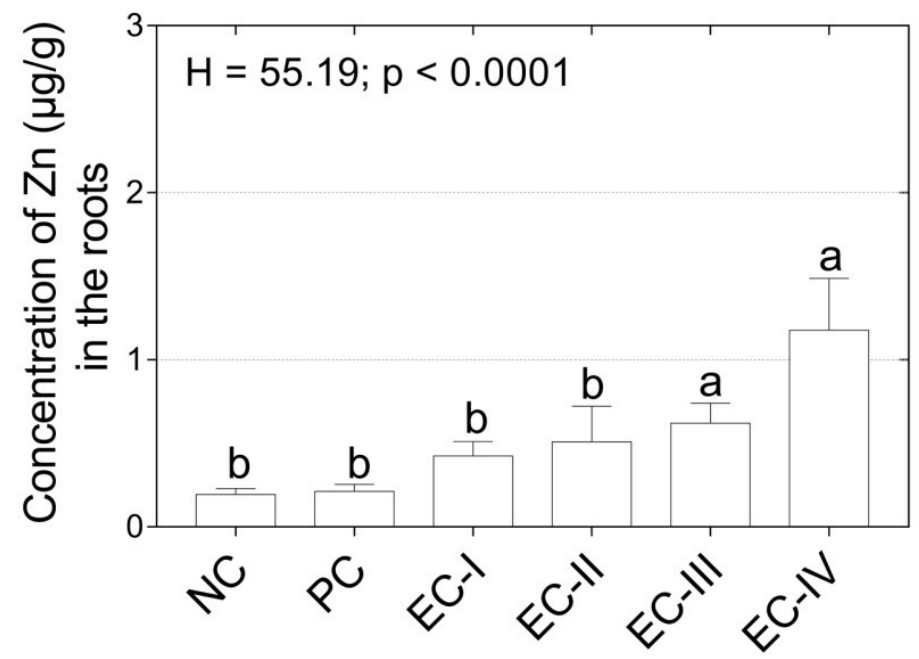

Figure 2. Zn bioaccumulation in a pool of root tissues of Allium cepa exposed, or not, to ZnO NPs. NC - negative control (pure water/reverse osmosis); PC - positive control (cyclophosphamide diluted in water); EC-I concentration $1.5 \mathrm{ng} / \mathrm{L}$; EC-II - concentration $360 \mathrm{ng} / \mathrm{L}$; EC- III - concentration 7.6x10 $\mathrm{ng} / \mathrm{L}$; EC- IV concentration $1 \times 10^{8} \mathrm{ng} / \mathrm{L}$.

It is known that $\mathrm{Zn}$ is an essential micronutrient for plant development, since, besides its function to help preventing diseases, it is an enzymatic cofactor in several biochemical cycles in plants, including photosynthesis, sugar formation, protein synthesis, fertility and seed production, and growth regulation (Singh et al., 2018). Zinc can cause phytotoxicity and, consequently, serious morphophysiological and cell damage at inappropriate concentrations. Previous studies have shown the cytotoxic and genotoxic damages caused by progressive $\mathrm{Zn}$ accumulation and distribution in the cytoplasm and nucleus of $A$. cepa (Kumari et al., 2011; Sun et al., 2019) and Vicia faba cells (Ghosh et al., 2016) after to exposure to high concentrations of ZnO NPs. Based on the present results, we can assume that low increase in accumulated $\mathrm{Zn}$ rates after the exposure to very low concentrations of $\mathrm{ZnO}$ NPs can have significant biological effect on plants and animals (Mesak et al., 2018; Souza et al., 2018).

\section{Microscopic analysis}

Based on the assays, ZnO NPs induced significant changes in MI and increase in CAI (Figure 3) as clear dose-response effect, even when plants were exposed to very low concentrations of them for a short period-of-time. Although MIs recorded 41.4 $\pm 2.1 \mathrm{EC}-\mathrm{I}$, and these numbers did not differ from that recorded for EC II $(40 \pm 1.4)$, the concentration of $\mathrm{ZnO}$ NPs in these two groups accounted for negative effects. This outcome was similar to that of numbers recorded for the PC group $(40 \pm 3.9)$, which were significantly different from those observed for the NC group $(50 \pm 5.4)$ (Figure $3 \mathrm{~A})$. In addition, the number of cells in each mitotic phase (Prophase, Metaphase, Anaphase and Telophase) significantly decreased as the number of ZnO NPs increased in comparison to the controls (NC and PC). This mitotic inhibition was associated with the progressive induction of different 
chromosomal anomalies $(\mathrm{r}=-0.97, \mathrm{P}<0.05)$ evidenced by CAs, which did not show any significant difference between groups EC-I $(2.1 \pm 0.9)$ and EC-II $(3.6 \pm 0.9)$. However, the damaging effects caused by the aforementioned treatments were similar to those expected for the PC group $(2.1 \pm 0.8)$, which were significantly different from results recorded for the $\mathrm{NC}$ group ( \pm 0.8 ). Both MI and CAs did not present significant differences (Figure $3 \mathrm{~A}$ and $3 \mathrm{~B}$ ) in the Pessimistic (EC-III) and Known Toxic (EC-IV) conditions. MI and CAs were significantly lower and higher under each of these conditions, respectively, in comparison to the other ones.
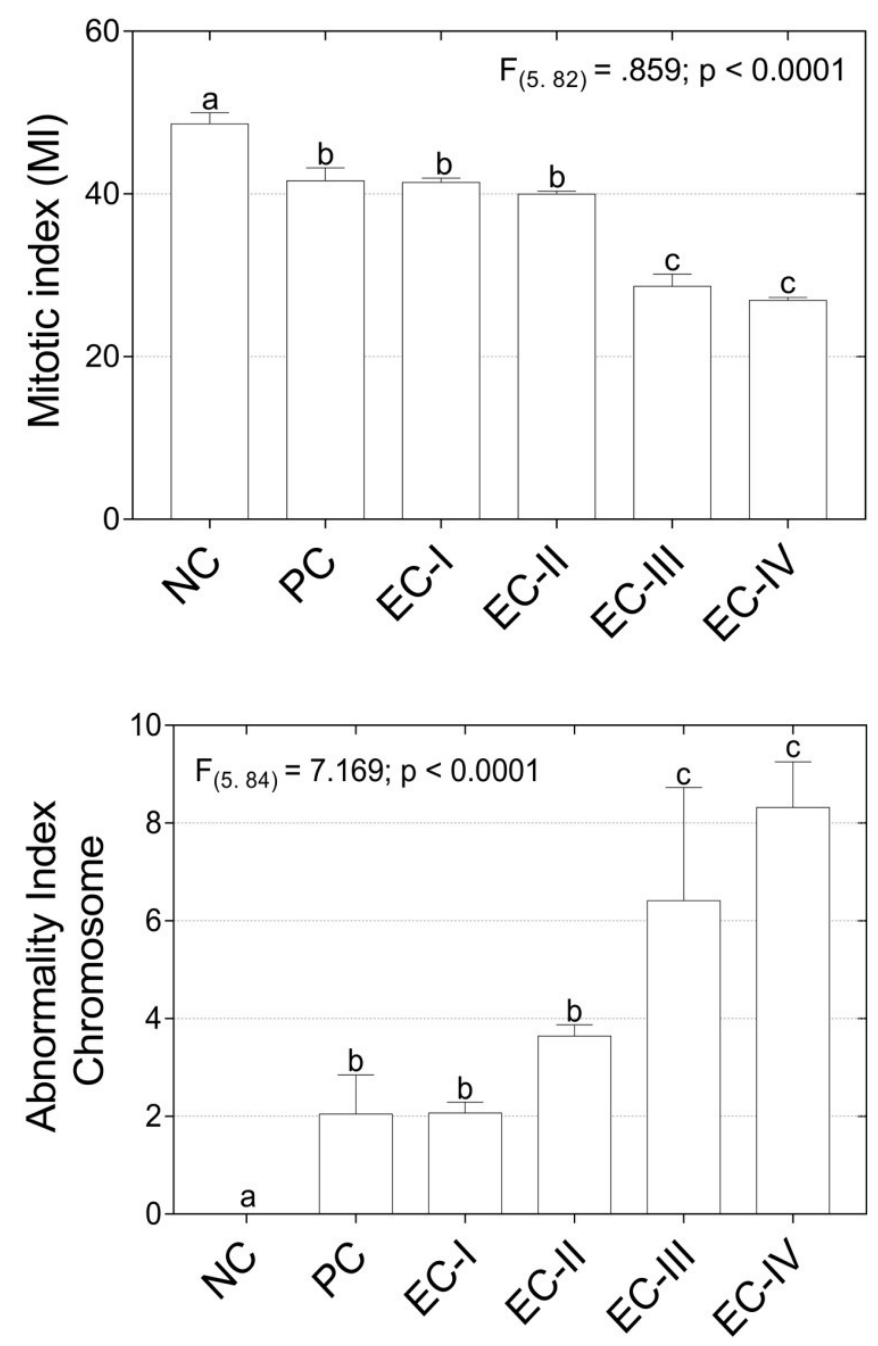

Figure 3. Mitotic index (A) and the index of cells presenting chromosomal abnormality (B) estimated from 15,000 meristematic cells of onion bulb roots exposed to different concentrations of ZnO NPs for $48 \mathrm{~h}$. NC negative control (pure water/reverse osmosis); PC - positive control (cyclophosphamide diluted in water); EC-I concentration $1.5 \mathrm{ng} / \mathrm{L}$; EC-II - concentration $360 \mathrm{ng} / \mathrm{L}$; EC-III - concentration 7.6x10 $\mathrm{ng} / \mathrm{L}$; EC-IV concentration $1 \times 10^{8} \mathrm{ng} / \mathrm{L}$. 
MI decrease and CAs increase due to increased concentrations of ZnO NPs was associated with the decrease in the root system growth of $A$. cepa seedlings, as expected. Onions in the negative control group had a significantly longer root system than the ones exposed to 1.5 and $300 \mathrm{ng} / \mathrm{L}, 7.6 \times 10^{5}$ and $1 \times 10^{8} \mathrm{ng} / \mathrm{L} \mathrm{NPs}$ of $\mathrm{ZnO}(\mathrm{P}<0.01)$. Moreover, the comparison between different conditions did not show significant differences, and compared to the positive control, except for onions exposed to the known toxic condition $\left(1 \times 10^{8} \mathrm{ng} / \mathrm{L} \mathrm{ZnO} N \mathrm{NP}\right)$ (Figure 4).

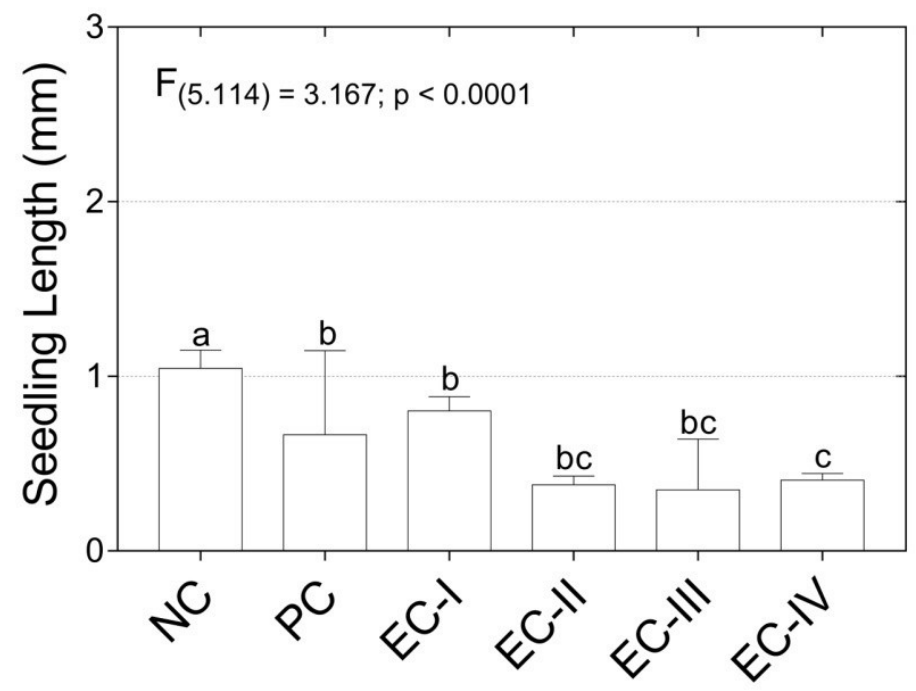

Figure 4. Total root-system length of onion seedlings exposed, or not, to different concentrations of ZnO NPs. NC - negative control (pure water/reverse osmosis); PC - positive control (cyclophosphamide diluted in water); EC-I - concentration $1.5 \mathrm{ng} / \mathrm{L}$; EC-II - $360 \mathrm{ng} / \mathrm{L}$ concentration; EC-III - concentration 7.6x10 $0^{5} \mathrm{ng} / \mathrm{L}$; EC-IV concentration $1 \times 10^{8} \mathrm{ng} / \mathrm{L}$.

Several chromosomal anomalies (CAs), such as bridges, polyploidy and clumped, laggard, fragmented, lost, disturbed and sticky chromosomes, were observed in the root meristem of onions exposed to different environmental concentrations of ZnO NPs (Table 1, Figure 5). The observed CAs presented two cell division phases, which were numerically higher at the metaphase than at the anaphase. Fragmented chromosome was the most frequent anomaly due to the high incidence of it in both cell division phases, when the total number of CAs was taken into consideration (Table 1). The other CAs were induced in only one of the herein mentioned cell division phases. The disturbance of clumped chromosomes in CAs was the most frequent anomaly in the metaphase and in the anaphase, respectively. Although this outcome is a counterpoint to results recorded by Sun et al. (2019) and Kumari et al. (2011), who found that chromosome stickiness was the most frequent CA, it corroborates the high DNA fragmentation increase observed in the comet assay carried out by Sun et al. (2019) and Ghosh et al. (2016) with A. cepa specimens. Ghosh et al. (2016) reported that most CAs were laggard and bridge chromosomes (anaphase and telophase), which suggests the involvement of the mitotic spindle. 


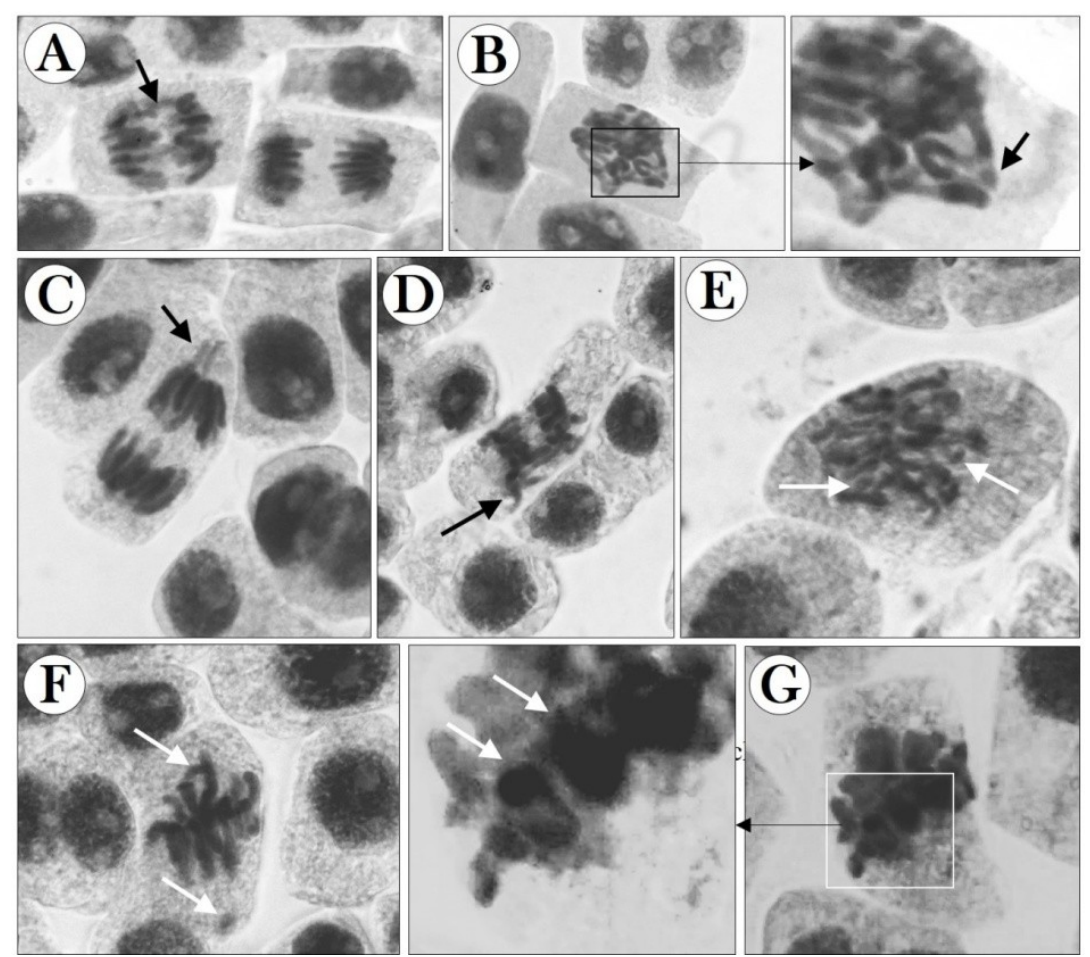

Figure 5 - Chromosomal abnormalities in the meristematic cells of Allium cepa roots exposed to environmentally relevant concentrations of $\mathrm{ZnO}$ NPs. (A): chromosome bridges (arrow); (B): Chromosomal break (arrow); (C): laggard chromosome in anaphase (arrow); (D): anaphase with evident chromosome breakage; (E and F): chromosomal fragment in metaphase; and $(\mathrm{G})$ : chromosome adherence (clumped metaphase). The slides were stained with Safranin, after fixation. However, a negative filter was applied to the photomicrographs to allow better visualizing the nuclear structure.

Table 1. Number of chromosomal abnormalities in Allium cepa root tip cells after exposed, or not, to different concentrations of ZnO NPs. NC - negative control (pure water/reverse osmosis); PC - positive control (cyclophosphamide diluted in water); EC-I - concentration $1.5 \mathrm{ng} / \mathrm{L}$; EC-II - $360 \mathrm{ng} / \mathrm{L}$ concentration; EC-III - concentration $7.6 \times 10^{5} \mathrm{ng} / \mathrm{L}$; EC-IV - concentration $1 \times 10^{8} \mathrm{ng} / \mathrm{L}$.

\begin{tabular}{|c|c|c|c|c|c|c|c|c|c|c|c|c|}
\hline \multicolumn{13}{|c|}{ Chromosomal abnormalities } \\
\hline \multirow{2}{*}{$\begin{array}{l}\text { Concentrations } \\
\text { (ng/L) }\end{array}$} & \multicolumn{6}{|c|}{ Metaphase } & \multicolumn{5}{|c|}{ Anaphase } & \multirow{2}{*}{ Total } \\
\hline & Polyploidy & Clumped & Fragments & Losses & Stickiness & Subtotal & Bridge & Laggard & Fragments & Disturbance & Subtotal & \\
\hline $\mathrm{NC}$ & 0 & 0 & 0 & 0 & 0 & 0 & 0 & 0 & 0 & 0 & 0 & 0 \\
\hline $\mathrm{PC}$ & 0 & 12 & 32 & 21 & 0 & 65 & 0 & 0 & 15 & 18 & 33 & 98 \\
\hline ES-I & 6 & 20 & 25 & 29 & 0 & 80 & 0 & 0 & 13 & 8 & 21 & 101 \\
\hline ES-II & 11 & 33 & 37 & 33 & 0 & 114 & 8 & 0 & 20 & 32 & 60 & 174 \\
\hline ES-III & 5 & 78 & 49 & 36 & 0 & 168 & 5 & 4 & 14 & 30 & 53 & 221 \\
\hline ES-IV & 19 & 65 & 49 & 61 & 5 & 199 & 21 & 0 & 10 & 38 & 69 & 268 \\
\hline Total & 41 & 208 & 192 & 180 & 5 & 626 & 34 & 4 & 72 & 126 & 236 & 862 \\
\hline
\end{tabular}

Laggard chromosomes at the anaphase were only observed in EC-III, and stickiness chromosomes at the metaphase (Figure 5) were only found in the Known Toxic treatment (EC-IV). CA laggard chromosomes resulted from chromosomes that lag behind or from chromosome fragments. The observed stickiness chromosomes may have been caused by 
chromosome DNA degradation and depolarization during the condensation process, which was already showed by Österberg et al. (1984). CA stickiness chromosome is an irreversible chromosome anomaly, which can lead to cell death (Turkoglu, 2012) assumingly, it is related to observed ghost cells.

Chromosome polyploidy at the metaphase (non-reversible anomaly) was observed under all tested concentrations, except for the controls (PC and NC). This CA may have been caused by the c-mitoses evidenced in the environmentally relevant concentrations and in the Known Toxic condition, different from Odeigah et al. (1997), who associated it with a weak toxic effect. In addition to the control groups, chromosome CA bridges at the anaphase (Figure 5) were not observed in EC-I since these CAs resulted from the fusion and break of chromosomes due to structural mutational processes. The other anomalies were observed in all treatments, except for the NC group. Similar genotoxic effect results were recorded for A. cepa exposed to different chemical substances (Chauhan et al., 1999; Celik et al., 2005; Srivastava and Mishra, 2009), as well as in taller plants exposed to high concentrations of NPs (Ghosh et al., 2016, Ghosh et al., 2019).

\section{DNA stability analysis}

According to RAPD data, 15 of the 27 amplification products were polymorphic, thus totaling $55.6 \%$ polymorphic bands in treatments based on seven primers. In total, $60 \%$ of this variation in comparison to the $\mathrm{NC}$ group derived from losses in amplified bands, whereas $40 \%$ of it resulted from band gain. PC (78.3\%) and EC-IV $(76.1 \%)$ recorded lower DNA stability than EC-I (89.1\%), EC-II (84.7\%) and EC-III (86.1\%) (Table 2).

Table 2 - Metrics of total changes in polymorphic amplification produced by RAPD primers from genomic DNA obtained from Allium cepa root cells exposed to different concentrations of ZnO NPs. PC: positive control, EC-I: $1.5 \mathrm{ng} / \mathrm{L}$ of ZnO NPs, EC-II: $360 \mathrm{ng} / \mathrm{L}$, EC-III: $7.6 \times 10^{5} \mathrm{ng} / \mathrm{L}$ and EC-IV: toxic scenario with $1 \times 10^{8} \mathrm{ng} / \mathrm{L}$; "a": presence of new bands, "b": absence of bands in comparison to the control; EG: Genomic Stability.

\begin{tabular}{|c|c|c|c|c|c|c|c|c|c|c|c|}
\hline \multirow{2}{*}{$\begin{array}{l}\text { RAPD } \\
\text { primers }\end{array}$} & \multirow{2}{*}{ Control } & \multicolumn{2}{|c|}{ PC } & \multicolumn{2}{|c|}{ ES-I } & \multicolumn{2}{|c|}{ ES-II } & \multicolumn{2}{|c|}{ ES-III } & \multicolumn{2}{|c|}{ ES-IV } \\
\hline & & $\mathbf{a}$ & b & $\mathbf{a}$ & b & $\mathbf{a}$ & b & $\mathbf{a}$ & b & $\mathbf{a}$ & b \\
\hline OPAC 1 & 2 & 0 & 0 & 0 & 0 & 0 & 0 & 0 & 0 & 0 & 1 \\
\hline OPAC 2 & 3 & 0 & 2 & 0 & 0 & 0 & 0 & 0 & 0 & 0 & 2 \\
\hline OPAC 6 & 4 & 0 & 0 & 0 & 3 & 0 & 1 & 1 & 0 & 0 & 2 \\
\hline OPAC 7 & 4 & 0 & 1 & 0 & 0 & 0 & 1 & 0 & 0 & 0 & 0 \\
\hline OPAC 12 & 4 & 4 & 0 & 0 & 0 & 3 & 0 & 3 & 0 & 3 & 0 \\
\hline OPAC 13 & 3 & 1 & 1 & 1 & 1 & 1 & 1 & 1 & 1 & 1 & 1 \\
\hline OPAC 17 & 3 & 0 & 1 & 0 & 0 & 0 & 0 & 0 & 0 & 0 & 1 \\
\hline Total & 23 & 5 & 5 & 1 & 4 & 4 & 3 & 5 & 1 & 4 & 7 \\
\hline $\begin{array}{l}\text { Average } \\
(\mathrm{a}+\mathrm{b})\end{array}$ & & 5 & & 2.5 & & 3.5 & & 3 & & 5.5 & \\
\hline EG (\%) & & 78.3 & & 89.1 & & 84.8 & & 86.9 & & 76.1 & \\
\hline
\end{tabular}

The new bands (new amplification products compared to the control, Table 2) indicate new conformations to the complementarity sites of primers available after the mutational events take place. This process suggests instability in the repair mechanism of mutated DNA. Losses or inhibition in DNA fragment amplification through RAPD were the main changes observed in plants after their exposure to $\mathrm{ZnO}$ NPs; this outcome is similar to 
results in reports about the toxic effects of fungicide Flusilazole on A. cepa (Ozakca and Silah 2013) and of benzo (a) pyrene aromatic hydrocarbon on Daphnia magna (Atienzar et al., 1999). According to these authors, changes in the electrophoresis profile of RAPD amplicon point out punctual mutations caused by complex rearrangements in chromosomes, which are induced by pollutants. According to Sun et al. (2019), the negative effects on the stability of the nucleic acid of $A$. cepa cells are caused by functional disorders induced by significant production of free radicals and by reactive molecule groups (ROS) after plant exposure to high concentrations of $\mathrm{ZnO} \mathrm{NPs}$. Assumingly, even low concentrations of $\mathrm{ZnO}$ NPs, induced the formation of ROS groups; moreover, they were related to inefficient repair mechanism in altered DNA. Based on the present results, the RAPD-PCR method was sensitive to the toxic effects of $\mathrm{ZnO} \mathrm{NPs}$, even at low concentrations for short-term exposure periods-of-time, since it was successful in detecting DNA damages related to genomic instability.

Based on these results, short-term exposure of eukaryotic plant cells to predicted environmentally relevant concentrations of $\mathrm{ZnO}$ NPs can damage $A$. cepa cells, and cause clastogenic (chromosome breakage promoters) and aneugenic effects related to the ability of these nanoparticles to depolymerize microtubules and cause cell disorders such as polyploid cells and chromosome loss. Root growth inhibition under different environmentally relevant concentrations has evidenced the toxicity of ZnO NPs, as well as the cytotoxic effects proven by MI decrease in comparison to the negative control (NC). Low concentrations of ZnO NPs caused genomic instability in A. cepa cells, as shown by the loss and gain of RAPD amplicons, which indicated dysfunction in DNA repair mechanisms. The hypothesis was confirmed: $\mathrm{ZnO}$ NPs, even at low concentrations, lead to biological damages and pose risk to cell functionality and to normal plant development.

\section{ACKNOWLEDGMENTS}

Thanks to Instituto Federal Goiano for the financial support and for the Scientific Initiation scholarship granted to the third author (IFGoiano Campus Urutaí). Moreover, the authors thank Abraão Tiago Batista Guimarães for his help in plotting the graphs in the GraphPad Prism software.

\section{CONFLICTS OF INTEREST}

The authors declare no conflict of interest.

\section{REFERENCES}

Atienzar AF, Conradi M, Evenden A, Jha A and Depledge M (1999). Qualitative assessment of genotoxicity using RAPD; comparison of genomic template stability with key fitness parameters in Daphnia magna exposed to benzo(a)pyrene. Environ. Toxicol. Chem. 18: 2275-2282.

Boxall ABA, Chaudhry Q, Sinclair C, Jones A, et al. (2007). Current and Future Predicted Environmental Exposure to Engineered Nanoparticles. Central Science Laboratory, The University of York.

Çelik M, Yuzbasioglu D, Unal F, Arslan O, et al. (2005). Effects of dinocap on the mitosis of Allium cepa L. Cytologia. 70: 13-22.

Chauhan LKS, Saxena PN and Gupta SK (1999). Cytogenetic effects of cypermethrin and fenvalerate on the root meristem cells of Allium cepa. Environ. Exper. Bot. 42: 181-189.

Dumont E, Johnson AC, Keller VDJ and Williams RJ (2015). Nano silver and nano zinc-oxide in surface waters Exposure estimation for Europe at high spatial and temporal resolution. Environ. Pollut. 196: 341-349. 
Fatma F, Verma S, Kamal A and Srivastava A (2017). Monitoring of mophortoxix, cytotoxic and genotoxic potential of mancozeb using Allium assay. Chemosphere. 195: 864-870.

Ghodake G, Seo YD and Lee DS (2011). Hazardous phytotoxic of cobalto and zinc oxide nanoparticles assessed using Allium cepa. J. Hazard. Mater. 186: 952-955.

Ghosh M, Ghosh I, Godderis L, Hoet P, et al. (2019). Genotoxicity of engineered nanoparticles in higher plants. Mutat. Res. 842: 132-145.

Ghosh M, Jana A, Sinha S, Jothiramajayam M, et al. (2016). Effects of ZnO nanoparticles in plants: Cytotoxicity, genotoxicity, deregulation of antioxidant defenses, and cell-cycle arrest. Mutat. Res. 807: 25-32.

Gottschalk F, Ort C, Scholz RW and Nowack B (2011). Engineered nanomaterials in rivers--exposure scenarios for Switzerland at high spatial and temporal resolution. Environ. Pollut. 159: 3439-3445.

Gottschalk F, Sun T and Nowack B (2013). Environmental concentrations of engineered nanomaterials: Review of modeling and analytical studies. Environ. Pollut. 181: 287-300.

International Zinc Association, ZincOx Resources plc [online] (accessed May 27, 2020). Available at: http://www.znox.com/industry/zinc-oxide.asp.

Kim TH, Kim M, Park HS, Shin US, et al. (2012). Size-dependent cellular toxicity of silver nanoparticles. J. Biomed. Mater. Res. 100A(4): 1033-1043.

Kumari M, Khan SS, Pakrahi S, Mukherjee A, et al. (2011). Cytogenetic and genotoxic effects of zinc oxide nanoparticles on root cells of Allium cepa. J. Hazar. Mater. 190: 613-621.

Kumari M, Mukherjee A and Chandrasekaran N (2009). Genotoxicity of silver nanoparticles in Allium cepa. Sci. Total. Environ. 407: 5243-5246.

Lin D and Xing B (2008). Root uptake and phytotoxicity of ZnO nanoparticles. Environ. Sci. Technol. 42: 5580-5.

Ma X, Geiser-Lee J, Deng Y and Kolmavok A (2010). Interactions between engineered nanoparticles (ENPs) and plants: Phytotoxicity, uptake and accumulation. Sci. Total. Environ. 408: 3053-3061.

Mesak C, Sampaio DMR, Ferreira RO, Mendes BO, et al. (2018). The effects of predicted environmentally relevant concentrations of $\mathrm{ZnO}$ nanoparticles on the behavior of Gallus gallus domesticus (Phasianidae) chicks. Environ. Pollut. 242: 1274-1282.

Modlitbová P, Porizka P, Novotny K, Drbohlavová J, et al. (2018). Short-term assessment of cadmium toxicity and uptake from different types of Cd-based Quantum Dots in the model plant Allium cepa L. Ecotox. Environ. Safe. 153: 23-31.

Odeigah PGC, Nurudeen O and Amund OO (1997). Genotoxicity of oil field wastewater in Nigeria. Hereditas. 126: 1617.

Österberg R, Persson D and Bjursell G (1984). The condensation of DNA by chromium (III) ions. J. Biomol. Struct. Dyn. 2: 285-290.

Ozakca DU and Silah H (2013). Genotoxicity effects of Flusilazole on the somatic cells of Allium cepa. Pest. Biochem. Physiol. 107: 38-43.

Rai M and Ingle A (2012). Role of nanotechnology in agriculture with special reference to management of insect pests. Appl. Microbiol. Biotechnol. 94: 287-293.

Singh A, Singh NB, Afzal S, Singh T, et al. (2018). Zinc oxide nanoparticles: a review of their biological synthesis, antimicrobial activity, uptake, translocation and biotransformation in plants. J. Mater. Sci. 53: 185-201.

Souza JM, Mendes BO, Guimarães ATB, Rodrigues ASL, et al. (2018). Zinc oxide nanoparticles in predicted environmentally relevant concentrations leading to behavioral impairments in male swiss mice. Sci. Total. Environ. 613-614: 653-662.

Srivastava K and Mishra K (2009). Cytogenetic effects of commercially formulated atrazine on the somatic cells of Allium cepa and Vicia faba. Pest. Biochem. Physiol. 93: 8-12.

Stroher A, Armijo CJV and Raffin RP (2010). Nanocosméticos: conceitos, vantagens e aplicações. Cosmetics Toiletries (Brasil). 22: 54-60.

Sun Z, Xiong T, Zhang T, Wang N, et al. (2019). Influences of zinc oxide nanoparticles on Allium cepa root cells and the primary cause of phytotoxicity. Ecotoxicology. 1-14.

Turkoglu S (2012). Determination of genotoxic effects of chlorfenvinphos and fenbuconazole in Allium cepa root cells by mitotic activity, chromosome aberration, DNA content, and comet assay. Pest. Biochem. Physiol. 103: 224-230.

Vance ME, Kuiken T, Vejerano EP, MCginnis SP, et al. (2015). Nanotechnology in the real world: Redeveloping the nanomaterial consumer products inventory. Beilstein. J. Nanotechnol. 6: 1769-1780.

Wang G. Nanotechnology: The New Features [online]. (accessed May 27, 2020). Available at: https://arxiv.org/pdf/1812.04939.pdf. 